PressAcademia Procedia

Istanbul Finance Congress, November 5-6, 2020

\title{
MARKET RISK PREMIUMS IN BIST 100 IN THE COVID ERA
}

\author{
DOI: 10.17261/Pressacademia.2021.1498 \\ PAP- V.14-2021(24)-p.110-112
}

\section{Suat Teker ${ }^{1}$, Dilek Teker ${ }^{2}$, Esin Demirel ${ }^{3}$}

${ }^{1}$ Isik University, Department of Business, Sile Campus, Istanbul, Turkey. suat.teker@isikun.edu.tr ,ORCID: 0000-0002-7981-3121

${ }^{2}$ Isik University, Department of Business, Sile Campus, Istanbul, Turkey. dilek.teker@isikun.edu.tr, ORCID: 0000-0002-3893-4015

${ }^{3}$ Isik University, Department of Business, Sile Campus, Istanbul, Turkey. esin.demirel@isikun.edu.tr, ORCID: 0000-0003-4257-6780

\section{To cite this document}

Teker, S., Teker, D., Demirel, E., (2021). Market risk premiums in BIST100 in the Covid-era. PressAcademia Procedia (PAP), 14, 110.112. Permanent link to this document: $h$ ttp://doi.org/10.17261/Pressacademia.2021

Copyright: Published by PressAcademia and limited licensed re-use rights only.

\section{ABSTRACT}

Purpose- Capital Asset Pricing Model (CAPM) is the most widely used and popular method in analysis of investment projects, stock valuation, firm valuation, mergers and acquisitions, initial public offerings and secondary public offerings. The determination of market risk premium is one of the most important inputs in the application of this model. The determination of market risk premium for the Turkish market has not deeply studied in the literature so far. This study intends to calculate the market risk premium for the Turkish Stock Market with a special emphasis on the Covid-19 era.

Methodology- The monthly data from the Reuters Database are collected for the BIST100 and 17 different sectoral indexes for the years of 2019 and 2020. Moreover, the monthly average short term interest rates on the Turkish Treasury Bonds are obtained from the database of Central Bank of Turkey for the years of 2019 and 2020. Based upon the historical observations, the market risk premium is defined as the difference in between the market index returns (BIST100 and 17 sectoral indexes) and the average short term interest rates on monthly basis.

Findings- The market risk premiums measured on BIST100 index are about $10 \%$ in 2019 and $20 \%$ in 2020 . The market risk premium is doubled in the Covid era. The volatilities of BIST100 index are $7.86 \%$ in 2019 and $8.15 \%$ in 2020 . The volatility of market risk premiums are also significantly increased in the Covid era.

Conclusion- Covid era has significantly increased the market risk premiums and volatilities of the Turkish market. The results of this study may be used as a reference study for local and international financial institutions, valuation industry and trade firms and academics for an approximation of market risk premium in the Covid era.

Keywords: Market risk premium, BIST100, sectoral market risk premiums, volatility.

JEL Codes: C58, G14, L93, E44

\section{REFERENCES}

Adjei, F. (2020). Effect of Economic Policy Uncertainty on Market Risk and Market Risk Premium. Journal of Finance and Economics, 8(2), 5760.

Ahn, S., \& Shrestha, K. (2009). Estimation of market risk premium for Japan. Journal Name: Enterprise Risk Management, 1(1), 33-43.

Arismendi-Zambrano, J., \& Azevedo, R. (2020). Implicit Entropic Market Risk-Premium from Interest Rate Derivatives. Available at SSRN: https://ssrn.com/abstract=3654217.

Baghdadabad, M. R. T. (2017). Retraction Note to: Traditional beta, average drawdown beta and market risk premium. Journal of Asset Management, 18(2), 155-155.

Bali, T. G., Cakici, N., \& Chabi-Yo, F. (2015). A new approach to measuring riskiness in the equity market: Implications for the risk premium. Journal of Banking \& Finance, 57, 101-117. 
Bhar, R., \& Chiarella, C. (2007). A Model for the Ex-Ante UK Stock Market Risk Premium. Journal of Applied Quantitative Methods, 5(4), 599606.

Blasi, P., Cohen, A., \& Simon, A. (2015). The determinants of historical property market risk premium in the London office market (No. eres2015_207). European Real Estate Society (ERES).

Bonga-Bonga, L. (2010). The assessment of market risk premium in South Africa. Journal of Applied Business Research (JABR), 26(6), 85-94.

Caporale, G. M., Gil-Alana, L. A., \& Martin-Valmayor, M. (2021). Persistence in the market risk premium: evidence across countries. Journal of Economics and Finance, 45(3), 413-427.

Chalamandaris, G., \& Rompolis, L. (2019). Recovering the Market Risk Premium from Stock and Option Prices. Available at SSRN: https://ssrn.com/abstract=2745879.

Chalamandaris, G., \& Rompolis, L. S. (2021). Recovering the market risk premium from higher-order moment risks. European Financial Management, 27(1), 147-186.

Chun, D., \& Cho, H. (2019). Short Interest and Market Risk Premium: The Case of the Korean Market. Korean Journal of Financial Studies, 48(5), 541-566.

Du, D., \& Hu, O. (2015). The world market risk premium and US macroeconomic announcements. Journal of International Money and Finance, 58, 75-97.

Fernández, P., Aguirreamalloa, J., \& Acín, I. F. (2015). Required Market Risk Premium among Countries in 2012. The Journal of Finance and Data Science, 1(1), 42-54.

Fernandez, P., Aguirreamalloa, J., \& Avendano, L. C. (2011). Market risk premium used in 56 countries in 2011: a survey with 6,014 answers. Available at SSRN 1822182: http://ssrn. com/abstract=1822182.

Fernández, P., Pershin, V., \& Fernández Acín, I. (2017). Discount rate (risk-free rate and market risk premium) used for 41 countries in 2017 : A survey. Available at SSRN: https://ssrn.com/abstract=2954142

Ferreira, T. S. V., Xavier, G. C., \& Martins, O. S. (2018). Political uncertainty and risk premium in the Brazilian stock market. Journal of Financial Innovation, early view, 62. doi: https://doi. org/10.15194/jofi 201

Fleckenstein, M., \& Longstaff, F. A. (2020). The Market Risk Premium for Unsecured Consumer Credit Risk (No. w28029). National Bureau of Economic Research. https://www.nber.org/papers/ w28029.

Graham, J. R., \& Harvey, C. R. (2015). The Equity Risk Premium in 2015. Available at SSRN: https://ssrn.com/abstract=2611793.

Gupta, P. K., Mittal, P., \& Hasan, N. (2018). Market Risk Premium Violations in Asset Pricing Models-A Higher Order Moments Approach. In Proceedings of Asia Conference on Business and Economic Studies (ACBES) by University of Economics Ho Chi Minh City on 8th-9th Sep 2018 at Ho Chi Minh City, Vietnam. UEH Publishing House, 62-71.

Harris, R. S., \& Marston, F. C. (2013). Changes in the Market Risk Premium and the Cost of Capital: Implications for Practice. Journal of Applied Finance (Formerly Financial Practice and Education), 23(1). Available at SSRN: https://ssrn.com/abstract=2686739.

Johnson, R., \& Soenen, L. (2009). Equity market risk premium and global integration. Journal of Centrum Cathedra, 2(1), 12-23. Available at SSRN: https://ssrn.com/abstract=1805161.

Kopchak, S. J. (2016). The regime-switching risk premium in the gold futures market. Journal of Economics and Finance, 40(3). 472-491.

Lally, M., \& Marsden, A. (2004). Estimating the market risk premium in New Zealand through the Siegel methodology. Accounting Research Journal, 17(2), 93-101.

Liu, Y. (2016). Labor Market Risk Premium: Empirical and Theory. Available at SSRN: https://ssrn.com/abstract=2639441.

Lie, E., Meng, B., Qian, Y., \& Zhou, G. (2017). Corporate activities and the market risk premium. Available at SSRN: https://ssrn.com/abstract=2911120

Lubis, I. (2021). Kurtosis and Skewness on Lagged Market Risk Premium in Indonesian Market During Covid 19 Pandemic. Jurnal Mandiri: Ilmu Pengetahuan, Seni, Dan Teknologi, 5(1), 46-60.

Naumoski, A., Arsov, S., Gaber, S., \& Gaber-Naumoska, V. (2016). Expected Equity Risk Premium: Survey Approach in the Case of a Small Emerging Market. Research Journal of Finance and Accounting, 7(2), 7-17.

Oikonomikou, L. E. (2015). Forecasting the Market Risk Premium with Artificial Neural Networks. Forecasting the Market Risk Premium with Artificial Neural Networks (November 2, 2015). Available at SSRN: https://ssrn.com/abstract=2743374.

Rizqiyana, A., \& Arfianto, E. D. (2019). Pengaruh Ambiguity, Market Risk Premium, Market to Book, Size, dan Momentum terhadap Return Saham pada Perusahaan yang Terdaftar dalam Indeks LQ45 Periode 2017-2018. Diponegoro Journal of Management, 8(4), 70-79. 
Salvi, A., Teti, E., \& Giakoumelou, A. (2019). The Relationship between LBOs, IPOs and Market Risk Premium. An Empirical Analysis of the European Market. International Journal of Business and Management, ISSN 1833-3850, 14(7), 160-170.

Shalaei, S. K., \& Hashemi, S. A. (2017). Studying the impact of accruals quality and market risk premium on stock return excess using FamaFrench three factor model. Journal of Politics and Law, 10, 15-56.

Soultanaeva, A., \& Strömqvist, M. (2009). The Swedish money market risk premium-experiences from the crisis. Economic review, 3. Available at SSRN: https://ssrn.com/abstract=163248.

Sum, V. (2012). Impulse response functions and causality test of financial stress and stock market risk premiums. International Journal of Financial Research, Vol. 4, No. 1, pp. 1-4. Available at SSRN: http://ssrn.com/abstract=2101572.

Xiao, Y., Colwell, D. B., \& Bhar, R. (2015). Risk premium in electricity prices: evidence from the PJM market. Journal of Futures Markets, 35(8), 776-793.

Yoshinaga, Y. (2017, June). Cyclical Trend of Aggregate Earnings and Market Risk Premium. In International Accounting Conference-2017.

Yoshinaga, Y. (2018). Cyclicality in Aggregate Earnings and the Market Risk Premium. Available at SSRN: https://ssrn.com/abstract=2977997. 